\title{
An empirical survey on factors influencing on packaging dairy products
}

\author{
Naser Azad* and Mina Mohammadi
}

Department of Management, Islamic Azad University, South Tehran Branch, Tehran, Iran

\begin{tabular}{|c|c|}
\hline$\overline{C H R O N ~ I ~ C ~ L E ~}$ & ABSTRACT \\
\hline $\begin{array}{l}\text { Article history: } \\
\text { Received January 18, } 2013 \\
\text { Received in revised format } \\
30 \text { May } 2013 \\
\text { Accepted } 25 \text { June } 2013 \\
\text { Available online } \\
\text { June } 262013 \\
\text { Keywords: } \\
\text { Dairy product } \\
\text { Packaging } \\
\text { Factor analysis }\end{array}$ & $\begin{array}{l}\text { Packaging plays an essential role on supplying different materials such as dairy products. The } \\
\text { first thing people may look into when they purchase dairy products such as milk, cheese, etc. is } \\
\text { associated with the packaging characteristics. This paper attempts to find important factors } \\
\text { influencing on packaging dairy products. The study uses factor analysis to detect important } \\
\text { factors based on a questionnaire consists of } 28 \text { questions in Likert scale, which is distributed } \\
\text { among } 200 \text { regular employees of Pegah dairy producer. Cronbach alpha, Kaiser-Meyer-Olkin } \\
\text { Measure of Sampling adequacy and Bartlett's test of Sphericity approximation Chi-Square are } \\
0.81 \text {, } 0.679 \text { and } 844.475 \text {, respectively and they are within acceptable limit. The study has } \\
\text { determined five factors including infrastructure, awareness, design and communication as } \\
\text { important factors influencing consumers. }\end{array}$ \\
\hline
\end{tabular}

\section{Introduction}

Packaging plays an important role on product development and gaining bigger market share (Olsson et al., 2004). When it comes to food based products and more specifically, dairy products, packaging becomes more important among consumers (Ahmed et al., 2005; Ampuero \& Vila, 2006; Noorani \& Setty, 2007). During the past few years, there have been tremendous efforts on detecting about important characteristics influencing packaging products. Azad and Masoumi (2012) performed a survey to detect important factors, which are influencing competitive advantage. They used sampling technique to measure characteristics of society and detected eight independent variables including packaging endurance, easy distribution, customer promotion through packaging, packaging structure, packaging as silent advertiser, diversity of packaging, clean and healthy packaging and innovation in packaging. 
Azad et al. (2012) investigated the relationship between packaging food products produced for children and parents' intentions to purchase these types of products. They used a questionnaire based on Likert scale, distributed it among the target population of this survey who were one of the wellknown food chain suppliers named Shahrvand, and analyzed them. They reported that there was a meaningful relationship between packaging children's food characteristics and parents' intention on purchasing product. They also reported that there was a positive relationship between children food packaging and the parent's priority purchasing decision.

Azad et al. (2013), in other study, presented an empirical investigation to detect important factors influencing on food market using factor analysis. The proposed study designed a questionnaire, distributed among 207 customers who were regular customers of two food chains in city of Tehran, Iran named Shahrvand and Hyperstar. The results of their survey indicated that six major factors including brand loyalty, physical characteristics, pricing effects, performance characteristics, brand relationship and brand position influenced food industry, significantly. In terms of the first factor, brand loyalty, "Trust”, "Packaging design characteristics", "Competitive pricing strategy", "Stability in quality", "External relationships" and "Meeting expectations" were important factors in various categories.

Azad et al. (2013) aimed to detect critical components of retail brand among some retail stores. The study tried to build a brand name in retail level and looked to find important factors influencing it. In their survey, customer behavior was largely affected when the first retail customer experience was formed. These factors have direct influences on customer experience and satisfaction in retail industry. The proposed study performed an empirical investigation on two well-known retain stores located in city of Tehran, Iran. Using a sample of 265 people from regular customers, the study used factor analysis and extracted four main factors including related brand, product benefits, customer welfare strategy and corporate profits using the existing 31 factors in the literature.

Giyahi (2012) presented an empirical study to measure the effects of chocolates' packaging on purchasing them. They reported that the number of purchased packages within a year, cost of purchasing chocolate within a year, type of relationship of recipients of chocolate as gift, gender of recipient of chocolate as gift, age group of recipient of gift, type of store, nationality of chocolate, significance of packaging in various price ranges, type of packaging, insertion of information on package and color of packaging, were important factors influencing people to buy more.

According to Azad and Hamdavipour (2012), Packaging plays an important role on marketing products and services in many competitive environments. A good packaging can increase sales of products, reduces the level of inventory, which yields to higher profitability. They studied the relationship between a good packaging program and customer's confidence as well as customer's attraction on purchasing goods and services. They used a questionnaire based on Likert scale and distributed among the target population of this survey and the information of packaging were divided into two groups of visibility and informative. The results indicated that a good label with detailed and precise information on product could significantly impact customer's confidence while other visible information did not have much impact on customer's confidence.

Mazdeh et al. (2011) presented a survey by asking experts to detect whether strategic planning is suitable for startups. They also proposed a model for strategic planning in startups based on the strategic planning models for small businesses and entrepreneurship concepts. The model was similar to other models and what differentiates this models form other approaches was the methodology used for internal and external analysis and the parameters taken into consideration. The proposed model was examined on an Iranian food packaging industry for validation. The preliminary results indicated that the success of startups depended on two sets of parameters: "entrepreneurial opportunities” and "competitive advantages and entrepreneurial characteristics". 


\section{The proposed study}

In this paper, we present an exploration study to find important factors influencing packaging dairy products in Iranian dairy industry. The proposed study designs a questionnaire consists of 28 questions and distributes it among 200 employees who work for one of the most popular dairy producers in Iran called Pegah. Cronbach alpha, Kaiser-Meyer-Olkin Measure of Sampling adequacy and Bartlett's test of Sphericity approximation Chi-Square are 0.81, 0.679 and 844.475, respectively and they are within acceptable limit. The study has determined five factors including infrastructure, awareness, design and communication, which are presented in details in next section.

\section{The results}

The proposed study of this paper has determined five important factors, which are explained in details in this section.

\subsection{The first factor: Infrastructure}

The first component of this survey is associated with infrastructures, which includes four subcomponents summarized in Table 1 as follows.

\section{Table 1}

The summary of factors influencing infrastructure

\begin{tabular}{lcccc}
\hline Option & Factor weight & Eigenvalues & \% of variance & Accumulated \\
\hline Durability & .846 & & & \\
Odor & .838 & & & \\
Texture & .401 & 2.259 & 8.069 & 8.069 \\
Materials & .342 & & & \\
\hline
\end{tabular}

As we can observe from the results of Table 1, Durability is number one priority followed by Odor, texture and materials. Cronbach alpha has been calculated as 0.704 for this factor.

\subsection{The second factor: Awareness}

Awareness is the second factor of this survey, which includes five sub-component and Table 2 demonstrates them in details as follows,

Table 2

The summary of factors affecting awareness

\begin{tabular}{lcccc}
\hline Option & Factor weight & Eigenvalues & $\%$ of variance & Accumulated \\
\hline Availability of production date & .662 & 1.978 & 7.064 & 15.133 \\
Availability of expiry date & .474 & & & \\
Producer's information & .472 & & & \\
Product specifications & .461 & & & \\
Brand name & .429 & & & \\
\hline
\end{tabular}

As we can observe from the results of Table 2, our experts believe that production data is the most important factor in promoting a product followed by expiry data. Other factors including producers' information, product specifications and brand name are also secondary important factors. Cronbach alpha is calculated as 0.735 , which is within acceptable desirable limit. 


\subsection{The third factor: Design}

Design is the third factor in our survey and it includes nine components summarized in Table 3 as follows,

\section{Table 3}

Different items associated with design perspective

\begin{tabular}{lcccc}
\hline Option & Factor weight & Eigenvalues & $\%$ of variance & Accumulated \\
\hline Writing style & .530 & 1.940 & 6.930 & 22.063 \\
Age & .514 & & & \\
Color & .438 & & & \\
Language & .438 & & \\
Shape & .426 & & \\
Gender & .414 & & \\
Graphics & .378 & & \\
Image & .366 & & & \\
Size & .302 & & & \\
\hline
\end{tabular}

It is surprising that among nine influencing factors, writing style plays an essential role followed by age, color, language, shape. While size and language of packaging does not seem to play important role on absorbing customers other factors such as shape, gender and graphics have some effects of design of a product. Cronbach alpha has been calculated as 0.785 , which is well above the minimum acceptable level. Design has extensively considered as an important factor on promoting a product (Lee \& Lye, 2003).

\subsection{Fourth factor: Technical}

The next important factor associated with our survey is associated with technical characteristics of packaging dairy products. This factor includes six items and they are summarized in Table 4 as follows,

Table 4

The summary of factors influencing Technical factors

\begin{tabular}{lcccc}
\hline Option & Factor weight & Eigenvalues & \% of variance & Accumulated \\
\hline Temperature & .562 & 1.926 & 6.878 & 28.941 \\
Environment & .538 & & & \\
Atmosphere & .498 & & & \\
Inventory & .492 & & & \\
Recycling & .454 & & & \\
Amount of air inside package & .420 & & & \\
\hline
\end{tabular}

The results of Table 4 demonstrate that temperature is the most important factor followed by environment. Other factors are believed to have the same level of importance among decision makers. Cronbach alpha has been calculated as 0.749 , which is within acceptable limit. Technical affairs have also been considered in other studies (Marsh \& Bugusu, 2007).

\subsection{The fifth factor: Communication}

Communication is the last factor in our survey and it demonstrates special features for conveying different messages to consumers. This factor includes four items and they are summarized in Table 5 as follows, 
Table 5

The summary of factors impacting communication with consumers

\begin{tabular}{lcccc}
\hline Option & Factor weight & Eigenvalues & \% of variance & Accumulated \\
\hline Easy features for opening & .591 & 1.733 & 6.190 & 35.131 \\
Motto & .528 & & & \\
Information about destination country & .387 & & & \\
\hline Logo & .387 & & & \\
\hline
\end{tabular}

The results of Table 5 emphasize one consumers' concern on easy opening features of dairy product followed by motto they use. In addition, it is necessary to add all product specification in language of destination country. Cronbach alpha has been calculated as 0.726 and it is within acceptable limit.

\section{Conclusion}

In this paper, we have presented an empirical investigation to study important factors influencing packaging in dairy product industry. The proposed model of this paper used factor analysis and detected five important factors including infrastructure, awareness, design and communication, which are presented in details in next section. In terms of infrastructure, durability is number one priority followed by Odor, texture and materials. In terms of product awareness, production data is the most important factor in promoting a product followed by expiry data. Other factors including producers' information, product specifications and brand name are also secondary important factors. In terms of technical factors, temperature is the most important factor followed by environment. Finally, communication was the last important factor, which influenced the consumers. In our survey, consumers' concerns on easy opening features of dairy product followed by motto they use are among the most important components. In addition, it is necessary to add all product specification in language of destination country.

\section{Acknowledgment}

The authors would like to thank Pegah diary producer for cordially supporting this survey.

\section{References}

Ahmed, A., Ahmed, N., \& Salman, A. (2005). Critical issues in packaged food business. British Food Journal Business, 107, 760-780.

Ampuero, O., \& Vila, N. (2006). Consumer perceptions of product packaging. Journal of Consumer Marketing, 23(2), 100-111.

Azad, N \& Masoumi, M. (2012). The impact of packaging on product competition. Management Science Letters, 2(8), 2789-2794.

Azad, N., Rafiee, M \& Hamdavipour, L. (2012). The role of children's food packaging characteristics on parent's purchasing decision. Management Science Letters, 2(3), 828-832.

Azad, N., Zarifi, S \& Hozouri, S. (2013). A factor analysis to find critical success factors in retail brand. Management Science Letters, 3(3), 827-832.

Azad, N \& Hamdavipour, L. (2012). A study on effects of packaging characteristics on consumer's purchasing confidence. Management Science Letters, 2(1), 397-402.

Azad, N., Seyedaliakbar, S., Hosseinzadeh, A \& Arabi, A. (2013). An exploration study on factors influencing Iranian food industry. Management Science Letters, 3(5), 1315-1322.

Giyahi, Y. (2012). An empirical study on the relationship of purchasing a chocolate based on its packaging. Management Science Letters, 2(3), 833-844.

Lee, S.G., \& Lye, S.W. (2003). Design for manual Packaging. International Journal of Physical Distribution and Logistics Management, 33(2), 163-189 . 
Marsh, K., \& Bugusu, B. (2007). Food packaging roles, materials, and environmental issues. Journal of Food Science, 72, 39-55 .

Noorani, H.S., \& Setty, K. (2007). Three steps for successful implementation of sales portals in CPG companies. International Journal of Retail and Distribution Management, 35 , 746-749 .

Olsson, A., Petterson, M., \& Johnson, G. (2004). Packaging demands in the food service industry. Food Service Technology, 4, 97-105.

Mazdeh, K., Mazdeh, M \& Moradi, K. (2011). Strategic planning model for Startups: A case study of Iranian packaging industry. Management Science Letters, 1(2), 157-166. 